Researches on Crustacea. No. 8 (1977)

Carcinological Society of Japan

Odawara Carcinological Museum

Azabu-Juban 3-11, Minatoku, Tokyo

\title{
松江にきた乾燥標本アメリカウミザリガニ
}

插図 2

上田常一

（松江市西川津町 3365-77）

前田 新 平

(米子市西三柳 4758)

\section{A DRIED SPECIMEN OF AMERICAN LOBSTER BROUGHT TO MATSUE}

With 2 Text-figures

by

Tsuneichi KAMITA

(3365-77 Nishi-Kawatsu, Matsue City)

and

Sinpei MAEDA

(4758 Ryo-mitsuyanagi, Yonago City)

\begin{abstract}
Recently a good dried specimen of American Lobster, Homarus americanus is placed on show in a corner of the first floor of the Matsue Branch of the Central Bank for Agriculture and Forestry. This lobster was caught 250 sea miles off the coast of New York City by a crew of the Ökuni-maru, a pelagic fishing vessel of Japan in January, 1974. The specimen is generally yellow-reddish brown coloured over the entire body, and measured $48 \mathrm{~cm}$ from the tip of rostrum to the posterior margin of telson. The carapace is $27 \mathrm{~cm}$ long including rostrum, and $21.5 \mathrm{~cm}$ excluding rostrum, with the width of $15 \mathrm{~cm}$. The two spines furnished on the under-surface of the rostrum, the characteristic of the species, are of anomalous shape as follows: knitted together at the bases and expanded like a roundish plate as shown in the Text-fig. 2, B.
\end{abstract}

山陰遠洋漁業株式会社（鳥取県境港水産会館内）所属の大国丸が，1974 年 1 月 New York 市沖 250 海里の大西洋で, 大きな lobster を捕獲した。それは乗班員が乾燥標本に仕上げて, 空路アメリカ経由境港市へ到着し，しばらく水産会館に出してあった。本文の揭載写真は当時 前田が撮影した。この乾燥 lobster は後に, 松江市殿町（県庁前）の農林中央金庫松江支所に 移され，ガラスふた付き底白の木箱の中に固定し，アメリカウミザリガニのラベルをつけて， 
一階のコーナーにかざってある。その名前がわかるまでには，次のようないきさつがあったと 聞いた。会社ではまずもよりの鳥取県水産試験場境分場にその名前を尋ねられ，分場では東海 区水産試験場や水産庁遠洋水産研究所に照会されて, アメリカウミザリガニに相違なしと認め られた。すなわち American Lobster*で，和名は海底に穴を掘ってそこに後ずさりするの意 である。

ウミザリガニ科 (Homaridae) に属し, 学名を Homarus americanus MILNE-EDWARDS とい5。ヨーロッパ種の H. gammarus (L.)=H. vulgaris M.-EDWARDS や南アフリカのケー プ種 H. capensis (HERBST) と共に，海産大型 lobster として有名である。分類上古くは

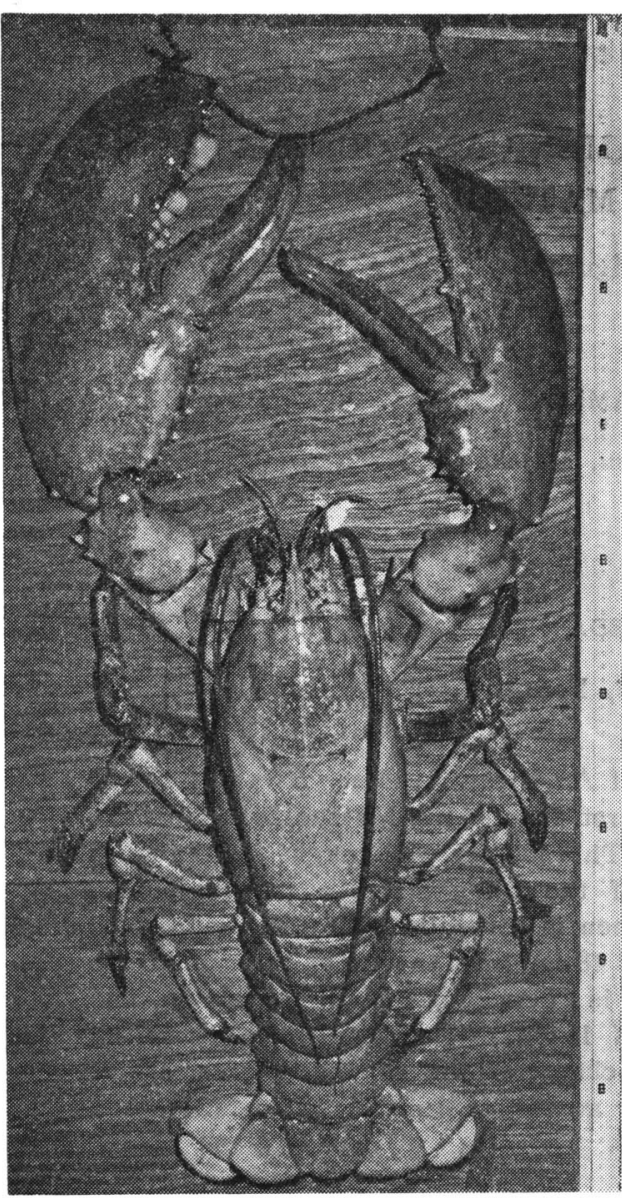

Text-fig. 1. 乾燥標本アメリカウミザリガニ Homarus vulgaris $(\hat{o} \times 0.15)$. Astacus 属に入れられていたが, Astacus BoRLASE, 1758 は river crayfish にあてられ, marine lobster には Homarus M.-EDWARDS, 1837 が用いられるようになった。

ネここで, この乾燥標本のアメリカウミザリ ガニは大きさが，額角の先端から尾節の末端ま での全長 $48 \mathrm{~cm}$, 標本姿勢に执いて第 1 胸脚を 加光ると $82 \mathrm{~cm}$, 額角を含む頭胸甲長 $27 \mathrm{~cm}$, 額角長 $5.5 \mathrm{~cm}$, 頭胸甲の最大幅部が $15 \mathrm{~cm}$ 。初 めて見る者はその巨大林なるに驚く。色彩はす っかり変色して黄味がかった赤かっ色*** であ る。

額角は真直にしてとがり先方が上曲し, 背面 中央縦に浅くてせまい溝がある額角の左側縁に 前・中・後位の 3 歯，右側縁に前・中位の 2 歯 をそな穴て対向し，それらの歯は後方へ至るに つれて小さくなる。手元の早標本 (全長 $33 \mathrm{~cm}$ ) では, 額角雨側に 3 歯対向しやはり後方ほど小 さい。額角下面は, 曲部において 2 個の棘（と げ）が基部でゆ着しながら拡張して円板状奇形 をなし，水平部に剛毛を列する。額角下面に 2 棘を有することは本種の重要な特徵であるが, 手元の早標本では 1 棘しかない。ヨーロッパ種 やアフリカのケープ 種の額角下面には棘はひと つもないのが特徴である。頭胸甲の背面前方に 8 歯あり,すなわち眼域の眼窩直後に 1 , 左右 の触角域に 2 ，甲の両側角に 1 歯をそなえる。

* アメリカの E. L. PALMER によれば (p. 372),カナダの Labrador 州からアメリカの North Carolina 州に至る大西洋岸に普通で, 3 日間に12マイル移動する。

** PALmer によれば（p. 372），大きさ $2 \mathrm{ft}$ (筆者注：61 cm) 重さ $28 \mathrm{lb}$ (筆者注：1.27 kg）を超える。 *** PALMER によれば（同上), 生時の色彩は背面暗緑色にして, 薄黒い斑点を有し, 下面は黄ばんでいる。 

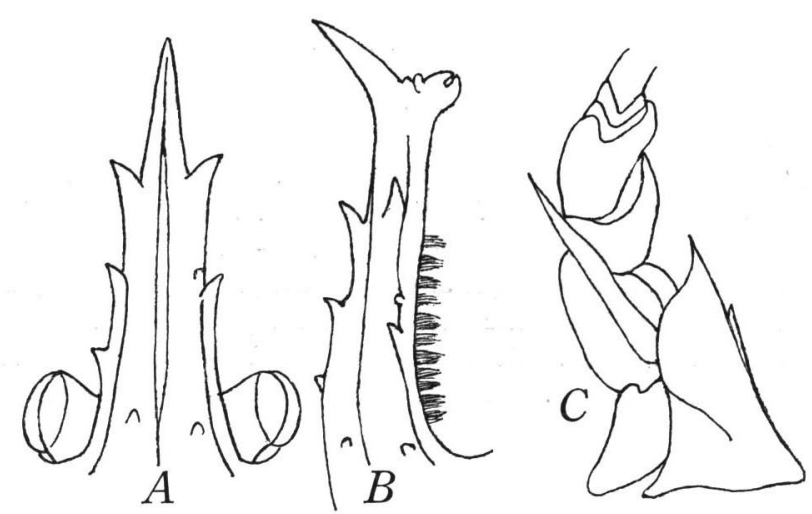

Text-fig. 2. アメリカウミザリガニの額角と触角. A, 額角背面; $\mathrm{B}$, 同側面とくに 2 棘の 奇形を示す； C, 第 2 触柄。（縮小率不同）

第 2 触角のりん片は小さく葉状をなし，触角べんは標本姿勢では後背方に曲げられ，先端は第 5 腹節に達す。

第 1 胸脚は左右不相称にして，左側のものは著しく大形（手元の 標本では右側が大形）で ある。掌節は幅広く表裏とも中高にして外縁部は弧状をなして扁平，関節部に近く 1 歯を有し 内側縁に 5 歯を列す。可動指（指節）は不動指より著しく幅せまく，外側面に 1 条の縦溝があ る。また，左側の不動指は内縁に丸久のある白い大歯を有し，それらの内で外方位のものは格 別大さく，可動指は不々ろいの小歯を列する。右側の不動指は多くの細歯を列するが注注中央 の 1 歯が大きく, 可動指は多くの細歯の久がならぶ。左右の腕節は背面に 2 歯, 内縁に 2 歯, 外縁に 3 歯を有す。第 1 腹肢は今にあっては鈎（かぎ）状をなし，京では正常である。雨者と もに尾扇が大きく発達する。

付記 本種の個体発生（変態）については，古く前世紀に扮いて S. I. SMITH が詳細に記載 した。T. Stebbing がその原図 3 葉を著書（p. 202）に転載し， E. L. PAlMER がその後の 学者の研究を併せて著書（p. 372）に述べているところでは，その生活史は次のよ5である。5 月に交尾し + は 6 月腹部の下面に 10 万粒の卵を抱く。翌年 5 月に ミシス期でもってふ化しゾエ 了期を省略する。稚エビは透明にして 2 か月間浅海の水面を遊泳し，第 6 回脱皮後に底生活に 入る。ふ化後 6 年大きさ $30 \mathrm{~cm}$ にして初めて交尾する。最も有用な甲殼類として, $30 \mathrm{~cm}$ を 超光るな゙漁獲をひか劣ることになっている。

謝辞 東京国立科学博物館の 武田正倫博士から，GORDON 博士が来朝寄贈のヨーロッパ種 （液漬）と西アフリカ産のケープ種（冷凍）の lobster を見せてもらった。東京水産大学水産 資源研究施設の小笠原義光教授が，飼育中死んだアメリカ種の 早（冷凍）を下さった。九州大 学名誉教授三宅貞祥博士が SCHELLENBERG や BARNARD の文献のコピーを作って下さった。 ここに深く感謝の意を表する。

な拈，フロリダ 国際大学生物科学教室の PATSY A. MCLAUGHLin 博士が， M. MilnEEDWARDS のアメリカウミザリガニの原記載（in: Histoire Naturelle des Crustacés, 1837, pp. 334〜335. Paris.) のコピーを送って下さった。深く感謝の意を表する。 
参考 文 献

BeLl, T. 1848. Lobster Homarus vulgaris Edw. in: A History of the British Stalk-eyed Crustacea, pp. 242-249.

Palmer, E. L. 1950(?) Lobster Homarus americanus. in: Fieldbook of Natural History, p. 372. Schellenberg, A. 1928. Homarus vulgaris M.-Edwards. in: Tierwelt Deutschlands und der Meerestile. 10 Teil, II. Decapoda, Zehnfüßer, pp, 52-56.

Stebbing, T. 1893. Astacus americanus (Milne-Edwards). in : A History of Crustacea, Recent Malacostraca. International Scientific Series vol. 74, pp. 203-205.

Barnard, K.H. 1950. Cape Lobster. Astacus capensis Herbst. in: Descriptive Catalogue of South African Decapod Crustacea. Annals of South African Museum. vol. 38, pp, 526-527. 